\title{
Pemahaman dan Preferensi Bahasa Masyarakat Indonesia pada Istilah Komputer dan/atau Internet
}

\author{
Alfelia Nugky Permatasari, S.S., M.A. ${ }^{1}$, PROF. DR. I Dewa Putu Wijana, S.U., M.A. ${ }^{2}$ \\ Universitas Gadjah Mada' \\ alfelia.nugky.p@ugm.ac.id \\ Universitas Gadjah Mada² \\ putu.wijana@ugm.ac.id
}

\begin{abstract}
Technology, including computers and internet, cannot be separated from Indonesians. At the beginning of computers and internet existence in Indonesia, the government took an initiative to make computers and internet equivalent terms through Presidential Decree No. 2 Year 2001. This aimed to ease Indonesians in using computers and/or internet. This effort then generated "Senarai Padanan Istilah" consisting of 711 equivalents from 629 English terms. This study aims to investigate Indonesians' comprehension, language preference, including their reason in choosing a particular language regarding computer and/or internet terms. The data were obtained from online questionnaire. The data obtained then were used to investigate Indonesians' comprehension of the terms as well as their language preference relating to the computer and/or internet terms. The results are then presented descriptively. This research results in: 1) Indonesians have a fairly high understanding related to computer and/or internet equivalent terms; 2) however, Indonesians prefer English to bahasa Indonesia, as many as $91.9 \%$ of the respondents; 3 ) English preference by the respondents is motivated by English terms familiarity, English terms ease to be understood, the lack of appropriateness of the equivalent terms, English shorter terms, and the unavailability of equivalent terms in the computer program they run.
\end{abstract}

Keywords: equivalent terms, computer, internet, comprehension, preferences

\section{Intisari}

Teknologi, termasuk di dalamnya komputer dan internet, sudah tidak dapat dipisahkan dari masyarakat Indonesia. Pada awal masuknya komputer dan internet di Indonesia, pemerintah berinisiatif untuk memadankan istilah di bidang tersebut dari berbahasa Inggris ke dalam bahasa Indonesia melalui Instruksi Presiden Nomor 2 Tahun 2001. Hal ini bertujuan untuk memudahkan masyarakat Indonesia ketika menggunakan komputer dan/atau internet. Usaha ini menghasilkan"Senarai Padanan Istilah" yang berisi 711 padanan dari 629 istilah berbahasa Inggris. Penelitian ini bertujuan untuk menyelidiki pamahaman, preferensi bahasa, serta alasan masyarakat Indonesia memilih bahasa tertentu terkait istilah komputer dan/atau internet melalui data yang diperoleh dari kuesioner online. Data kemudian dianalisis dan disajikan secara deskriptif. Temuan penelitian antara lain masyarakat Indonesia memiliki pemahaman cukup tinggi terkait padanan istilah komputer dan/atau internet; akan tetapi, preferensi masyarakat Indonesia jatuh pada bahasa Inggris, tepatnya sebanyak 91,9\% responden. Preferensi bahasa Inggris dilatarbelakangi oleh 1) istilah berbahasa Inggris dirasa lebih umum, 2) istilah berbahasa Inggris lebih mudah dipahami, 3) istilah berbahasa Inggris lebih singkat, 4) padanan istilah kurang sesuai, 5) tidak tersedianya padanan istilah pada program komputer yang mereka jalankan.

Kata kunci: padanan istilah, komputer, internet, pemahaman, preferensi 


\section{Pendahuluan}

Teknologi, termasuk di dalamnya teknologi informasi, merupakan bidang yang cukup pesat perkembangannya. Bangsa-bangsa barat, sebagai bangsa penemu berbagai macam teknologi, dianggap lebih maju di bidang ini jika dibandingkan dengan negara berkembang seperti Indonesia. Dari sini, dapat ditafsirkan bahwa dalam teknologi informasi, bahasa Inggris lebih dominan daripada bahasa Indonesia. Perbedaan peradaban ini membuat bahasa Indonesia menjadi penyerap unsur-unsur bahasa Inggris pada bidang tersebut.

Sebagai bangsa penemu, para penutur bahasa Inggris tadi memiliki kebebasan menciptakan istilah-istilah yang digunakan untuk merujuk hasil temuannya. Lain halnya dengan bangsa pemakai temuan-temuan yang dimaksud. Bangsa pemakai teknologi temuan bangsa lain akan cenderung menyerap istilah dari bahasa dari masyarakat tutur penemu teknologi. Kata 'komputer' misalnya, diserap bahasa Indonesia dari bahasa Inggris computer. Dari contoh ini, dapat dilihat bagaimana bahasa Inggris, yang dituturkan oleh masyarakat penemu komputer, lebih dominan jika dibandingkan dengan bahasa Indonesia yang hanya berperan sebagai pemakai hasil temuan dalam bidang teknologi berupa komputer.

Dewasa ini, komputer dan internet sudah tidak dapat dipisahkan dari masyarakat Indonesia. Ermanesty (t.t.) di dalam artikelnya menyatakan bahwa sejarah komputer di Indonesia sendiri dimulai dari masuknya komputer ke Indonesia pada tahun 1967. Mulai tahun 2000-an penggunaan komputer sudah menjadi bagian dari masyarakat Indonesia. Di sisi lain, pada awal kemunculannya, internet merupakan jaringan komputer yang dibentuk oleh Departemen Pertahanan Amerika Serikat pada tahun 1969 dan digunakan untuk tujuan militer. Setelah berkembang di barat, internet masuk ke Indonesia pada tahun 1990-an. Pada tahun 2017, dalam salah satu lamannya, Kementrian Komunikasi dan Informatika Republik Indonesia (2018) mencatat bahwa pengguna internet aktif di Indonesia telah mencapai lebih dari 112 juta orang. Dengan angka tersebut, Indonesia menempati peringkat ke-5 di dunia.

Semakin signifikannya eksistensi komputer dan internet di Indonesia pada saat itu membuat pemerintah memandang perlu adanya usaha untuk menyediakan padanan istilah-istilah 
komputer dalam bahasa Indonesia. Usaha

ini berupa pelaksanaan Instruksi Presiden

Nomor 2 Tahun 2001 tentang Penggunaan

Komputer dengan Aplikasi Komputer

Berbahasa Indonesia. Peng-Indonesia-an

istilah ini pada mulanya bertujuan untuk memudahkan masyarakat Indonesia menguasai penggunaan dan pemanfaatkan komputer di Indonesia. Hal ini bermula dari anggapan bahwa penguasaan teknologi komunikasi dan informasi dengan penggunakan komputer serta jaringannya tersendat dengan terbatasnya penguasaan bahasa Inggris, yang merupakan operasional komputer. Usaha tersebut menghasilkan 711 padanan istilah-istilah komputer dalam bahasa Indonesia dari 629 istilah dalam bahasa Inggris. Daftar padanan ini kemudian diberi judul "Senarai Padanan Istilah".

Jika dilihat dari awal kemunculannya di tahun 2001, dapat ditarik kesimpulan bahwa "Senarai Padanan Istilah" telah ada selama 15 tahun hingga tahun 2016. Waktu tersebut selayaknya sangat cukup untuk suatu istilah dipahami kemudian digunakan oleh suatu masyarakat dalam merujuk hal-hal di bidangtertentu. Namun, pada perkembangannya, istilahistilah bidang komputer dan internet yang telah dipadankan ini seakan kurang dipahami oleh masyarakat Indonesia. Widagsa (2011) bahkan menemukan bahwa dari penggunaan 150 istilah pada bidang internet, hampir semua respondennya menggunakan istilah bahasa Inggris pada sebuah forum diskusi online mengenai bidang tersebut. Hanya dua padanan istilah dalam bahasa Indonesia saja yang digunakan oleh pengguna internet. Dari sini dapat diasumsikan bahwa masyarakat Indonesia belum banyak mengetahui adanya padanan istilah-istilah bidang komputer dan internet. Jika dilihat dari beberapa hal seperti dari tahun dikeluarkannya Senarai Padanan Istilah, telah diberikannya pendidikan komputer di sekolah-sekolah, serta jumlah pengguna komputer dan internet $\mathrm{di}$ Indonesia pada saat ini, seharusnya masyarakat Indonesia lebih paham akan padanan istilah-istilah tersebut dan dapat menggunakannya dengan baik pada konteks yang sesuai.

Penelitian ini berawal dari keprihatinan akan minimnya pengetahuan masyarakat Indonesia tentang padanan istilah-istilah komputer dan internet. Tujuan dari penelitian ini adalah untuk mengetahui sejauh mana pengetahuan masyarakat Indonesia akan padanan istilah komputer dan internet Jurnal Lingua Applicata Volume 2 Nomor 1 September 2018 
yang tersedia di "Senarai Padanan Istilah", serta preferensi bahasa yang digunakan dalam merujuk istilah-istilah komputer dan internet berikut faktor atau alasan masyarakat Indonesia memilih istilah-istilah komputer dan internet baik dalam bahasa Inggris ataupun padanannya dalam bahasa Indonesia.

Proses pemadanan istilah tidak lepas dari proses serapan kosa kata oleh bahasa satu terhadap bahasa lainnya. Terdapat beberapa tulisan berkaitan dengan unsur bahasa asing yang diserap ke dalam bahasa Indonesia. Badudu telah menuliskan idenya dalam tiga jilid buku Inilah Bahasa Indonesia yang Benar (1983, 1986, dan 1989) juga dalam Cakrawala Bahasa Indonesia (1985). Eddy juga menulis buku yang kemudian diberi judul Unsur Serapan Asing dalam Bahasa Indonesia (1989). Soedjarwo (1990) telah melakukan penelitian yang berfokus pada aspek morfologi kata-kata serapan dalam bahasa Indonesia, khususnya proses afiksasi, misalnya pada akhiran -is dan -ik pada kata 'akademis' dan 'linguistik'. Selain itu, telah disusun pula kamus yang memuat kata-kata serapan asing pada bahasa Indonesia, seperti yang telah dituliskan Badudu (2007) dan Martinus (2001).
Penelitian lebih mendalam mengenai kata-kata serapan bahasa Inggris dalam bahasa Indonesia dilakukan oleh Lowenberg (1983). Selain menyelidiki aspek-aspek kebahasaan, penelitian ini juga mempertimbangkan faktor sosial politik dan juga historis yang mempengaruhi masuknya unsur-unsur serapan bahasa Inggris dalam bahasa Indonesia. Pada aspek kebahasaan, Lowenberg menemukan bahwa penyerapan leksikal pada kata-kata bahasa Inggris yang diserap dalam bahasa Indonesia mengalami dua proses fonemis, yaitu penyerapan secara total dan sebagian. Penyerapan total maksudnya penyerapan unsur dalam bahasa Inggris dilakukan secara menyeluruh, baik ejaan maupun pengucapannya, misalnya kata technology yang dalam bahasa Indonesia diserap menjadi 'teknologi'. Penyerapan sebagian memiliki arti bahwa bahasa Indonesia hanya menyerap sebagian unsur pada bahasa Inggris, misalnya kata adaptation menjadi 'adaptasi'.

Syafar (2012) dalam tesisnya mengkaji kata-kata serapan bahasa Inggris dalam bahasa Indonesia dari sisi morfologi dan semantiknya. Dalam tesisnya, Syafar menggunakan data yang diperoleh dari surat kabar yang kemudian 
dianalisis menggunakan dua teori Haugen (1972), yaitu proses pemasukan dan proses penyulihan. Analisis morfologis digolongkan menjadi tiga golongan utama, antara lain: kata simpleks atau kata dasar yang meliputi nomina, verba, dan ajektiva; kata kompleks yang telah mengalami proses morfologis berupa afiksasi; dan kata majemuk serapan dari bahasa Inggris berupa ajektiva dan nomina. Syafar membahas pula perubahan makna kata serapan bahasa Inggris dalam bahasa Indonesia. Perubahan makna yang ditemukan yaitu perubahan makna total, menyempit, amelioratif, dan peyoratif. Selain itu, Syafar juga menuliskan alasan-alasan penyerapan bahasa Inggris dalam bahasa Indonesia, antara lain: kehematan, kemudahan dan kesingkatan; dorongan gengsi; memenuhi kebutuhan register tertentu; nuansa makna; dan memenuhi kebutuhan eufimisme.

Selain beberapa tulisan sebelumnya, terdapat pula penelitian-penelitian yang berfokus pada peristilahan pada bidang internet. Penelitian-penelitian tersebut salah satunya dilakukan oleh Rahayu dan Aminudin (2013) yang diberi judul Kajian Kebahasaan Terhadap Peristilahan Internet. Pada penelitian ini, Rahayu dan Aminudin mengacu pada Pedoman
Pembentukan Istilah (P3BI). Data yang digunakan dikumpulkan melalui penelusuran internet yang kemudian disusun sesuai abjad lengkap dengan maknanya. Penelitian ini menghasilkan kategori istilah-istilah internet dalam bahasa Indonesia, antara lain: bentuk padanan, bentuk asli dan bentuk singkatan. Bentuk padanan merupakan bentuk yang paling banyak ditemukan. Rahayu dan Aminudin beranggapan bahwa melalui penemuan ini, dapat diasumsikan bahwa bahasa Indonesia berpotensi positif dapat menjadi bahasa modern dalam bidang teknologi dan ilmiah.

Penelitian lain mengenai perstilahan internet ditulis oleh Widagsa (2011). Dalam tesisnya, Widagsa mendeskripsikan pemakaian peristilahan atau register bahasa Inggris dalam bidang internet. Penelitian ini menjelaskan tiga hal, antara lain: bentuk peristilahan bahasa Inggris dalam bidang internet, makna peristilahan bahasa Inggris dalam bidang internet; dan pemberian padanan register bahasa Inggris dalam bidang internet ke dalam bahasa Indonesia dan penggunaannya. Data diambil dari forum Internet Service and Networking pada komunitas Kaskus. Widagsa menemukan sekurang-kurangnya 109 register bahasa 
Inggris dalam bidang internet. Dari 109 register tersebut, hanya 24 register bahasa Inggris yang mendapat padanan kata melalui P3BI. Penemuan ini semakin menarik karena dari keseluruhan register yang menjadi data, hanya dua padanan saja yang digunakan oleh pengguna internet. Pada akhir bagian, Widagsa menyebutkan bahwa alasan penggunaan register bahasa Inggris dalam bidang internet tersebut adalah untuk mempersingkat tuturan dan meminimalkan ambiguitas makna.

Berbeda dari penelitian-penelitian sebelumnya, data penelitian ini merupakan peristilahan dalam bidang komputer dan internet yang telah melalui proses peng-Indonesia-an yang tertulis dalam "Senarai Padanan Istilah". Hal ini berarti, istilah-istilah tersebut sudah dibakukan dan telah secara resmi dianggap menjadi bagian dari kekayaan bahasa Indonesia. Terhitung sejak dikeluarkannya pada tahun 2001, jika usaha pemadanan atau peng-Indonesiaan istilah-istilah tersebut berjalan dengan baik, masyarakat Indonesia pengguna internet tentunya dapat mengenali dan memahami istilah-istilah tersebut. Beberapa istilah yang terdaftar dalam "Senarai Padanan Istilah" dipilih dan disertakan dalam kuesioner secara sistematis. Kuesioner ini kemudian digunakan untuk mengetahui sejauh mana pemahaman masyarakat Indonesia pengguna komputer dan internet dalam bahasa Indonesia. Kemudian diselidiki juga preferensi bahasa untuk peristilahan di bidang komputer dan internet serta alasan mereka memilih bahasa tersebut.

\section{Metodologi Penelitian}

Penelitian ini menggunakan pendekatan kualitatif yang dibantu dengan pendekatan kuantitatif. Data yang digunakan dalam penelitian ini diperoleh dengan menggunakan teknik rekam dan catat (Kesuma, 2007) terhadap 160 responden. Dalam pemerolehan data, kuesioner dibuat untuk menyelidiki sejauh mana pengetahuan orang Indonesia terhadap istilah-istilah bidang komputer dan internet.

Kuesioner yang dipakai memiliki dua bagian. Bagian pertama merupakan kuesioner tertutup yang jawaban pertanyaannya sudah disediakan. Bagian ini digunakan untuk menyelidiki tingkat pendidikan responden ketika pertama kali mendapatkan pelajaran komputer di pendidikan formal juga sejauh mana penutur bahasa Indonesia memahami 
padanan istilah komputer dan internet. Pertanyaan yang diajukan berupa pilihan tertutup, yaitu mulai Taman Kanak-Kanak (TK), Sekolah Dasar (SD), Sekolah menengah Pertama (SMP), Sekolah Menengah Atas (SMA), dan lainnya. Selanjutnya, daftar sampel sejumlah 100 padanan istilah diambil dari "Senarai Padanan Istilah" secara sistematis untuk menyelidiki pemahaman masyarakat Indonesia terhadap padanan istilah komputer dan/atau internet. Dalam menyusun kuesioner, dalam jumlah yang merata, padanan istilah yang dipilih terdiri dari istilah-istilah yang masing-masing dipadankan dengan proses loadwords, loanblends, loanshifts (Haugen, 1972). Setiap sampel istilah kemudian diberikan pilihan seperti 'Tidak Paham', ‘Pernah Dengar', 'Paham' ‘Bukan Istilah Komputer dan/atau Internet'. Pada awal kuesioner, dijabarkan pengertian dari pilihan-pilihan jawaban tersebut.

Bagian kedua merupakan kuesioner terbuka di mana responden memiliki kebebasan lebih untuk menyampaikan jawaban atas pertanyaan yang diajukan. Pertanyaan pada bagian ini digunakan untuk menyelidiki preferensi bahasa masyarakat Indonesia dalam merujuk istilah komputer dan/atau internet. Selain itu, bagian ini juga digunakan untuk menyelidiki alasan atau latar belakang yang mempengaruhi para penutur bahasa Indonesia dalam menggunakan istilah komputer dan internet dalam bahasa Indonesia. Selengkapnya, tahapan pengumpulan data digambarkan pada bagan berikut.

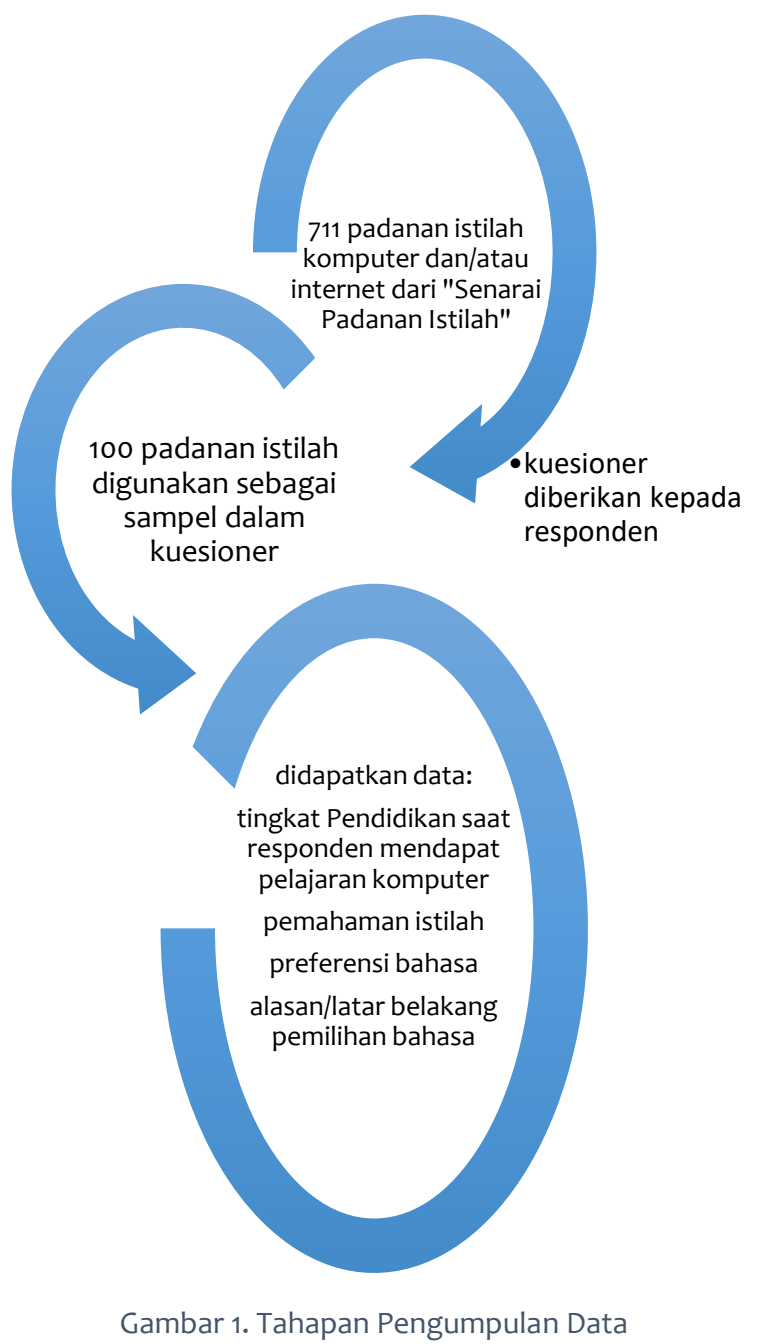

Kuesioner dibuat secara online menggunakan fasilitas google docs yang tersedia di laman https://goo.gl/uWgaWj. Responden dalam penelitian ini adalah masyarakat pengguna komputer dan internet di Indonesia yang berusia 20-30 
tahun. Hal ini dengan asumsi bahwa mereka telah mendapatkan pendidikan komputer secara formal di sekolah pada saat "Senarai Padanan Istilah" dikeluarkan. Pengambilan data dilakukan dari tanggal 17 Juni 2016 sampai 21 Juni 2016. Dari tenggat waktu tersebut, didapatkan 160 responden.

Data yang telah didapatkan dari kuesioner dianalisis untuk mengetahui sejauh mana penutur bahasa Indonesia memahami padanan istilah komputer dan internet dalam bahasa Indonesia. Selanjutnya, dijabarkan pula data yang didapat dari kuesioner bagian kedua untuk mengetahui alasan preferensi bahasa penutur bahasa Indonesia dalam menggunakan istilah-istilah komputer dan internet. Data kemudian disajikan dengan menggunakan metode informal, yaitu dengan kata-kata pada umumnya (Sudaryanto, 1993).

\section{Hasil dan Pembahasan}

Dalam kenyataannya, peristiwa penyerapan unsur kata yang kemudian digunakan dan diakui oleh masyarakat penutur bahasa serapan tidak berlangsung dalam waktu singkat. Terdapat pula latar belakang peristiwaperistiwa lain yang mendukung proses penyerapan bahasa. Beberapa ahli bahasa seperti Bloomfield (1995) dan Thomason (2001) menguraikan bagaimana berbagai macam peristiwa tertentu melatarbelakangi proses penyerapan bahasa. Haugen (1972) kemudian menjelaskan secara lebih rinci bagaimana penyerapan unsur bahasa berlangsung dari segi morfologis dan fonetisnya.

\section{Kontak Bahasa}

Beberapa ahli linguistik seperti Bloomfield (1995) dan Haugen (1972) setuju bahwa bahasa selalu berkembang. Salah satu hal yang memungkinkan fenomena tersebut terjadi adalah peristiwa kontak bahasa. Thomason (2001, h. 1) mendefinisikan kontak bahasa sebagai peristiwa penggunaan lebih dari satu bahasa dalam tempat dan waktu yang sama. Dalam praktiknya, penggunaan bahasa ini tidak menuntut penutur untuk dapat berbicara lancar sebagai seorang bilingual atau multilingual. Penutur mungkin hanya memasukkan sejumlah kosa kata atau frasa dari bahasa lain dalam tuturannya saat berkomunikasi.

Pada uraian lain, Thomason (2001) menyebutkan faktor-faktor penyebab terjadinya kontak bahasa. antara lain: (1) bertemunya dua kelompok yang 
berpindah ke daerah yang tak berpenghuni; (2) perpindahan satu kelompok ke wilayah kelompok lain; (3) adanya praktik pertukaran buruh atau budak secara paksa; (4) adanya hubungan budaya yang dekat antar sesama tetangga lama; dan (5) adanya kontak pendidikan atau kontak belajar. Penelitan ini berfokus pada faktor terakhir yang disebutkan Thomason (2001), yaitu adanya kontak pendidikan. Bahasa Inggris, yang memiliki penutur paling banyak di dunia, dianggap sebagai lingua franca oleh masyarakat. Bahasa ini pun banyak digunakan sebagai bahasa pengantar dalam berbagai disiplin ilmu seperti komunikasi, sosial, budaya, teknologi, dan lain sebagainya. Bahasa ini mau tidak mau menjadi unsur serapan pada bahasa lain yang dituturkan pengguna komputer dan internet. Tidak terkecuali bahasa Indonesia, yang masyarakatnya juga menjadi salah satu pengguna komputer dan internet terbanyak di dunia.

\section{Unsur Serapan}

Pada saat kontak bahasa terjadi, salah satu bahasa dapat menyerap unsur dari bahasa lainnya. Chaer (2008) mendefinisikan penyerapan ini sebagai pengambilan kosakata dari bahasa asing. Istilah kata serapan berasal dari loan word yang seringkali disebut juga sebagai kata pinjaman. Kridalaksana (2008) menganggap loan word sebagai kata pinjaman. Kata pinjaman ini kemudian didefinisikan sebagai kata yang dipinjam dari bahasa lain dan kemudian sedikitbanyaknya disesuaikan dengan kaidah bahasa sendiri. Winford yang juga didukung oleh van Coestem dalam Hickey (2013) memfokuskan pada agen yang berperan dalam proses peminjaman. Beliau mengambil kesimpulan bahwa suatu proses dapat disebut sebagai peminjaman jika proses perpindahan materi linguistik dari bahasa sumber ke dalam bahasa peminjam atau penerima, dilakukan oleh agen dari penutur bahasa penerima.

Proses penyerapan atau peminjaman dianggap memiliki dampak positif bagi bahasa penyerap unsur-unsur bahasa lain. Fromkin dkk (2011) mengungkapkan bahwa peminjaman kata-kata dari bahasa lain merupakan sumber penting akan kata-kata baru, yang kemudian disebut kata serapan pada bahasa peminjam. Proses ini terjadi ketika suatu bahasa menambahkan sebuah kata atau morfem dari bahasa lain ke dalam leksikonnya. Dalam uraiannya, Fromkin dkk (2011) juga menambahkan bahwa proses penyerapan ini seringkali terjadi 
pada situasi kontak bahasa, ketika penutur bahasa-bahasa yang berbeda berinteraksi terus-menerus satu sama lain, dan khususnya ketika terdapat banyak penutur bilingual atau multilingual.

\section{Perubahan pada Unsur Serapan}

Perubahan paling dasar pada unsur serapan adalah pada tataran fonologisnya. Hal ini sejalan dengan pernyataan Haugen (1972) bahwa perubahan paling sederhana dan paling umum terjadi adalah perubahan di mana penutur bahasa penerima berusaha untuk meniru unsur serapan seperti bunyi aslinya. Pada kasus ini, penutur bahasa peminjam berusaha memproduksi pola bunyi yang sama untuk merujuk pada unsur yang dimaksud. Hal ini tidak akan menjadi masalah bunyi dalam unsur serapan dimiliki oleh kedua bahasa. Ketika terdapat bunyi yang tidak dimiliki oleh bahasa peminjam, penutur bahasa yang meminjam unsur tersebut akan memproduksi bunyi paling mirip yang dimiliki bahasanya. Haugen (1972) selanjutnya menyatakan bukan tidak mungkin jika kemudian penutur bahasa yang diserap sama sekali tidak memahami kata atau unsur yang dimaksud, contohnya kata drama pada bahasa Inggris yang berubah menjadi dorama ketika diucapkan oleh penutur bahasa Jepang.

Selain pada tingkat fonetis, unsur serapan juga berubah pada tataran morfologi bahasa penerima. Berkaitan dengan hal ini, Winford dalam Hickey (2013) menyatakan bahwa peminjaman leksikal biasanya diadaptasikan pada fonologi dan morfologi dari bahasa penerima. Setelah proses adaptasi ini, besar kemungkinan unsur-unsur tersebut menjadi tak terpisahkan dari bahasa penerimanya. Hal ini karena morfemmorfem unsur serapan pada bahasa asal telah disesuaikan dengan bahasa penerima. Jika kata tesebut merupakan gabungan antara morfem dari bahasa asli dan bahasa penerima, Haugen (1972) menyebutnya sebagai bentuk hybrid.

Perubahan sintaksis dapat terjadi pula pada unsur serapan dalam bahasa penerima meskipun perubahan ini seakan cukup kompleks jika dibandingkan dengan tingkatan perubahan sebelumnya. Hal tersebut dianggap perlu karena unsur serapan diharapkan menyesuaikan bentuknya agar dapat diterima oleh penutur bahasa penerima. Sejalan dengan pernyataan tersebut, Winford dalam Hickey (2013) mengungkapkan bahwa pada semua kasus, unsur pinjaman dimanipulasi agar 
mereka memenuhi aturan struktural dan semantis bahasa penerimanya. Pada istilah-istilah komputer dan internet, perubahan struktural ini dapat dilihat pada tingkat frasa.

Terdapat istilah-istilah bidang komputer dan internet yang berupa frasa dari "Senarai Padanan Istilah". Chaer (1994) mendefinisikan frasa sebagai satuan gramatikal yang berupa gabungan kata yang bersifat nonpredikatif, atau lazim juga disebut gabungan kata yang mengisi salah satu fungsi sintaksis di dalam kalimat. Menurut Ramlan (1987), frasa adalah satuan gramatik yang terdiri dari dua kata atau lebih yang tidak melebihi batas unsur klausa. Berdasarkan fungsi dari unsur penyusunnya, frasa dibedakan menjadi frasa endosentris dan eksosentris. Frasa endosentris merupakan frasa berkonstituen inti, yang kemudian dibagi lagi menjadi frasa endosentris atributif, frasa endosentris koordinatif, dan frasa endosentris yang apostif (Chaer, 1994). Di lain pihak, frasa eksosentris merupakan frasa yang salah satu unsur pembentuknya menggunakan kata tugas, seperti 'dari Bandung', 'kepada teman', dan 'di kelurahan'.

Chaer (1994) selanjutnya menjelaskan perbedaan antara frasa endosentris atributif, frasa endosentris koordinatif, dan frasa endosentris yang apostif. Frasa endosentris atributif merupakan frasa endometris yang terdiri atas konstituen-konstituen tidak setara. Di dalamnya terdapat konstituen berstatus sebagai konstituen inti dan atribut atau penjelas, misalnya 'dosen sintaksis', 'bahasa saya', dan 'rumah besar'. Frasa endosentris koordinatif adalah frasa enosentris yang terdiri atas konstituen-konstituen yang setara. Semua penyusun frasa ini adalah konstituen inti, misalnya 'tua muda' dan 'ibu bapak'. Frasa endosentris yang apositif merupakan frasa yang masingmasing konstituennya dapat saling menggantikan, misalnya 'Dian temanku' dan 'Rudi si penari jalanan'.

Frasa pada istilah-istilah komputer dan internet merupakan frasa endosentris atributif. Frasa ini memiliki unsur diterangkan (D) dan menerangkan (M). Pada bahasa Inggris, pola frasanya menggunakan kaidah menerangkanditerangkan (MD) sedangkan pada bahasa Indonesia, polanya diterangkanmenerangkan (DM). Perbedaan ini menyebabkan perubahan sintaksis pada penyerapan unsur istilah komputer dan internet seperti yang dapat dilihat pada frasa data processor menjadi 'pemroses data'. Terdapat juga frasa verba Jurnal Lingua Applicata Volume 2 Nomor 1 September 2018 
koordinatif seperti pada 'kemas dan jalankan' dari pack and go. Beberapa contoh frasa verba lain dalam Senarai Padanan Istilah yaitu 'turun halaman', 'tulis ulang', 'ganti judul', dan 'coba lagi'. Padanan-padanan istilah ini berturutturut berasal dari page down, rewrite, rename, dan retry.

\section{Jenis Kata Serapan}

Haugen (1972) membedakan kata serapan menjadi tiga kelompok besar berdasarkan tingkat importation atau pengambilan unsur-unsurnya dan subtitusi morfem dari bahasa asalnya. Kelompok yang pertama adalah Loanwords. Loanwords menunjukkan adanya pengambilan morfem tanpa substitusi. Kelompok ini terdiri dari semua morfem bebas yang telah diambil tanpa substitusi apapun, kecuali infleksi minimal dan penyesuaian fonemis yang dianggap perlu, misalnya kata 'monitor', 'komputer', 'desain', dan 'manajemen'. Kelompok yang kedua adalah Loanblends. Loanblends menunjukkan adanya pengambilan dan substitusi morfem. Kelompok ini terdiri dari serapan yang mengandung substitusi parsial atau sebagian di luar infleksi yang terdapat pada kelompok pertama. Pada kelompok ini, morfem dari kedua bahasa yang mengalami kontak bercampur menghasilkan bentuk hibrida (hybrid), misalnya hyperlink menjadi 'hipertaut'. Kelompok yang terakhir adalah Loanshifts. Loanshifts menunjukkan substitusi morfemis tanpa adanya pengambilan morfem. Kelompok ini terdiri dari serapan di mana seluruh morfem bahasa asal digantikan oleh morfem lain pada bahasa penerima. Kelompok ini juga biasa disebut sebagai loan translation atau semantic loan. Istilah shift atau pergeseran digunakan karena pergeseran ini muncul pada bahasa peminjam hanya sebagai pergeseran fungsional dari morfem asalnya. Contoh serapan yang termasuk dalam kelompok ini adalah download menjadi 'unduh' dan erase menjadi ‘hapus'.

\section{Pemahaman Bahasa}

Dalam berkomunikasi, suatu masyarakat tutur telah memahami bahasa yang digunakannya. Pemahaman ini termasuk peristilahan di bidang tertentu yang dirujuk dalam tuturannya. Sudijono (2008) mendefinisikan pemahaman sebagai kemampuan seseorang untuk mengerti dan memahami setelah sesuatu itu diketahui dan diingat. Dengan kata lain, memahami adalah mengerti akan suatu hal dan mampu melihatnya dalam berbagai segi. Jika seseorang dapat memberikan Jurnal Lingua Applicata Volume 2 Nomor 1 September 2018

Hal. 51 
penjelasan atau uraian yang lebih rinci mengenai hal yang dimaksud menggunakan kata-kata sendiri, orang tersebut dapat dikatakan paham. Sudijono (2008) yang didukung oleh Bloom, et. Al. (1956) juga menyebutkan bahwa pemahaman merupakan jenjang kemampuan berfikir yang lebih tinggi dibandingkan ingatan atau hafalan.

Bangsa Indonesia yang menempati urutan kelima dunia dalam penggunaan internet telah familier dengan peristilahan di bidang tersebut. Istilahistilah bidang komputer dan internet yang merupakan serapan dari bahasa Inggris harus dipahami dengan baik agar pengguna komputer dan internet dapat berkomunikasi dengan baik dalam bidang tersebut. Jika tidak, bukan tidak mungkin akan terjadi kesalahpahaman atau ketidakberhasilan komunikasi antar pengguna komputer dan internet yang satu dengan lainnya.

\section{Preferensi Bahasa}

Kata serapan muncul karena konsep yang dikandung dalam kata yang dimaksud belum ada di bahasa penyerap atau penerima. Katamba dalam Syafar (2012) berpendapat bahwa seringkali, yang terjadi kemudian adalah penutur bahasa yang sebelumnya tidak memiliki konsep tersebut harus menggunakan kata yang digunakan oleh masyarakat bahasa pemilik konsep itu. Kata-kata tersebut kemudian disesuaikan dengan bahasa penyerap, seperti pelafalan, ejaan, bahkan mungkin bentuk sintaksisnya. Bukan tidak mungkin penutur bahasa penerima kemudian menggunakan istilah dalam bentuk asli dari bahasa pemilik konsep tersebut.

Berkaitan dengan hal yang disebutkan sebelumnya, Eddy (1989) menjabarkan empat latar belakang pemakaian istilah bahasa asing, antara lain: (1) kekurangan materi, yaitu terbatasnya istilah bahasa penyerap dalam bidang tertentu, seperti bidang teknologi; (2) menciptakan kemegahan, di mana bahasa asing dianggap lebih bergengsi dibandingkan bahasanya ibunya; (3) ekonomi dan pariwisata, keberlangsungan dan pertumbuhan bidang ini dianggap sangat dipengaruhi oleh hubungan atau interaksi dengan negara lain yang mau tidak mau menuntut penyerapan istilah-istilah asing yang berkaitan dengan kedua bidang tersebut; dan (4) bentuk bertahan, maksudnya bentuk penyerapan yang secara sengaja mempertahankan bentuk bahasa asing karena pada kenyataannya istilah tersebut telah biasa digunakan oleh masyarakat penutur bahasa penerima. 
Di sisi lain, dalam kaitannya dengan masalah kebahasaan, Marcellino dalam Syafar (2012) menyebutkan empat faktor penyebab masuknya kosakata asing ke dalam bahasa Indonesia, antara lain: (1) kebutuhan mengisi kekosongan perbendaharaan kata bahasa Indonesia; (2) kebutuhan memberikan kecukupan (sufficiency) pengertian di bidang linguistik; (3) kebutuhan memenuhi suatu register tertentu; dan (4) kesediaan menerima (receptivity) kosakata dari bahasa yang dipinjam.

\section{Pemahaman Padanan Istilah Komputer}

\section{dan Internet Masyarakat Indonesia}

Survey yang dilakukan terhadap 160 responden berusia 20-30 tahun terhadap pemahaman padanan istilah komputer dan internet menghasilkan data yang diilustrasikan pada bagan berikut.

\section{Perbandingan Level Pendidikan} Responden Saat Pertama Kali Mendapat Pelajaran Komputer

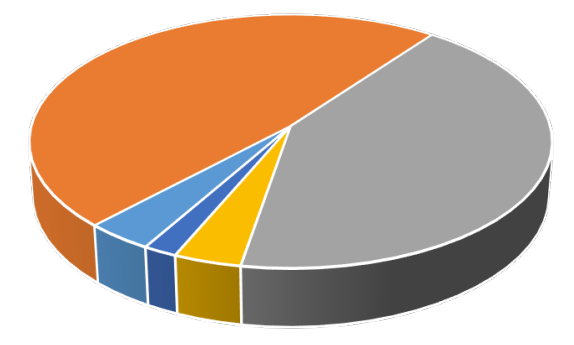

-TK - SD - SMP - SMA - Lainnya

Gambar 2. Perbandingan Level Pendidikan Responden Saat Pertama Kali Mendapat Pelajaran Komputer
Sumber: Data Penelitian 2016

Dari 160 responden, enam responden atau sekitar 3,8\% dari mereka mendapatkan pelajaran komputer sejak Taman Kanak-Kanak, 77 atau 48,1\% responden mendapatkan pelajaran komputer sejak Sekolah Dasar, 68 atau $42,5 \%$ responden mendapatkan pelajaran komputer sejak Sekolah Menengah Pertama, enam atau $3,7 \%$ responden mengaku mendapatkan pelajaran komputer sejak Sekolah Menengah Atas, dan tiga atau 1,9\% responden lainnya menjawab lainnya. Dari jumlah ini dapat diasumsikan bahwa hampir seluruh responden memiliki latar belakang pengetahuan yang cukup mengenai istilah komputer dan internet dari pendidikan formal mereka.

Secara umum, jika dilihat dari persentase tertinggi dari setiap jawaban pada 100 padanan yang diberikan, pemahaman masyarakat Indonesia dapat dikatakan cukup tinggi. Untuk lebih jelasnya digambarkan pada bagan berikut. 
Pemahaman Masyarakat Indonesia

Tentang Istilah Komputer dan/atau Internet

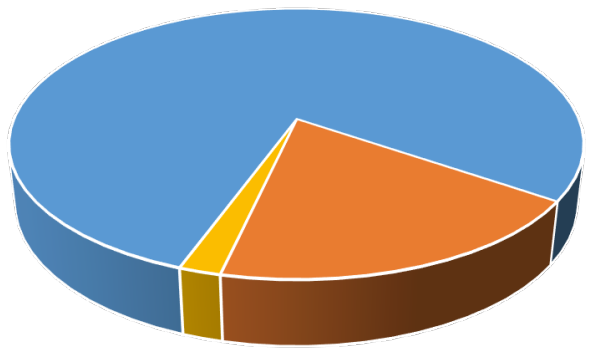

- Paham

- Tidak Paham

- Pernah Dengar

- Bukan Istilah Komputer dan/atau Internet

Gambar 3. Pemahaman Masyarakat Indonesia Tentang Istilah Komputer dan/atau Internet Sumber: Data Penelitian 2016

Dari 100 sampel padanan istilah dan yang diberikan kepada 160 responden, sebanyak $79 \%$ atau 79 istilah mendapat jawaban 'Paham' terbanyak. Keadaan ini disusul oleh 19\% atau 19 istilah yang mendapat jawaban 'Tidak Paham' paling banyak, kemudian $2 \%$ atau dua istilah yang dianggap kebanyakan responden bukan merupakan istilah komputer dan/atau internet. Padanan istilah ini adalah 'penyangga' yang berasal dari bentuk asli buffer dan 'pembelajaran' dari bentuk asli instruction. Istilah 'penyangga' memiliki definisi tempat penyimpanan data sementara, sering digunakan ketika transmisi data harus mengambil tempat pada kecepatan yang berbeda (di sini Jurnal Lingua Applicata Volume 2 Nomor 1 September 2018 buffer mengakumulasi data dari peralatan berkecepatan rendah). Istilah ini juga dapat ditemui dalam dunia perangkat keras, yaitu alat yang meluaskan sinyal, memperbesar kemampuan drive. Istilah 'pembelajaran' memiliki definisi pernyataan untuk melaksanakan suatu tugas dalam bahasa pemrograman, misalnya copy, print, dan lain-lain.

\section{Preferensi Bahasa Masyarakat Indonesia} dalam Menggunakan Istilah Komputer dan Internet

Pemahaman masyarakat Indonesia pada padanan istilah komputer dan internet yang cukup tinggi, yang ditunjukkan sebanyak 79\% oleh kuesioner, tidak kemudian membuat mereka memilih bahasa Indonesia ketika menggunakan istilah-istilah komputer dan internet. Hal ini terlihat pada jawaban para reponden pada pertanyaan kuesioner tentang bahasa manakah yang lebih nyaman mereka gunakan ketika berkaitan dengan istilah komputer dan internet yang secara rinci digambarkan pada bagan berikut. 


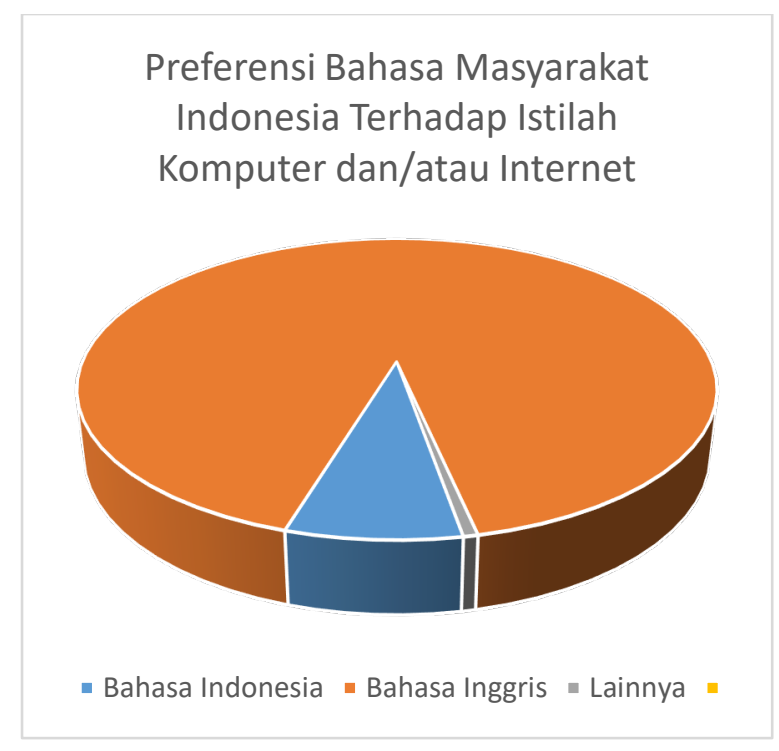

Gambar 4. Preferensi Bahasa Masyarakat Indonesia

Terhadap Istilah Komputer dan/atau Internet

Sumber: Data Penelitian 2016

Dari bagan di atas terlihat jelas bagaimana masyarakat Indonesia pengguna justru memilih bahasa Inggris untuk merujuk pada istilah-istilah di bidang komputer dan/atau internet. Dari survey yang dilakukan kepada 160 responden, sebanyak 147 atau 91,9\% responden memilih bahasa Inggris. Hanya 12 atau $7,5 \%$ saja yang memilih bahasa Indonesia, dan satu sisanya memilih pilihan lainnya.

Beragam alasan atau latar belakang mereka memilih bahasa tertentu diungkapkan oleh responden pengguna komputer dan internet tersebut. Dari uraian jawaban mereka, responden yang mengaku memilih bahasa Indonesia beralasan bahwa mereka kurang mampu dalam berbahasa Inggris dan terbiasa menggunakan bahasa Indonesia dalam kehidupan sehari-hari. Di sisi lain, dari responden yang memilih bahasa Inggris, dapat disimpulkan bahwa terdapat sekurang-sekurangnya lima alasan mengapa mereka lebih memilih menggunakan istilah komputer dan internet dalam bahasa Inggris. Alasanalasan tersebut sebagai berikut:

1) Istilah dalam Bahasa Inggris Lebih Familier

$\begin{array}{lll}\text { Sebanyak } & 121 & \text { responden }\end{array}$ menyebutkan bahwa alasan mereka memilih bahasa Inggris dalam menyebutkan istilah-istilah bidang komputer dan internet adalah karena mereka merasa lebih familier atau terbiasa dengan istilah-istilah dalam bahasa tersebut. Mereka mengaku bahwa sejak awal mereka mengenal dan belajar tentang komputer dan internet, mereka selalu menggunakan istilah-istilah dalam bahasa Inggris. Bahkan, pada pendidikan formal mereka, para guru komputer dan buku-buku panduan yang mereka gunakan, menggunakan istilahistilah komputer dan internet dalam bahasa Inggris. Hampir tidak ada panduan yang menggunakan padanan istilah komputer dan internet dalam bahasa Indonesia. Beragam aplikasi, program, dalam komputer dan internet yang Jurnal Lingua Applicata Volume 2 Nomor 1 September 2018 
beredar di Indonesia juga didominasi dengan bahasa Inggris. Baru beberapa tahun ini bahasa Indonesia mulai dijadikan pilihan dalam aplikasi maupun program komputer. Namun, karena sedari awal dan selama bertahun-tahun para responden tadi terlanjur terbiasa dengan istilah-istilah dalam bahasa Inggris, mereka justru mengaku kesulitan jika menggunakan pilihan bahasa Indonesia. Padanan istilah dalam bahasa Indonesia yang ada justru kurang dapat dipahami oleh mereka.

\section{2) Istilah dalam Bahasa Inggris Lebih}

\section{Mudah Dipahami}

$\begin{array}{rlr}\text { Sebanyak } & 33 & \text { responden } \\ \text { menyebutkan } & \text { bahwa } & \text { ketika }\end{array}$
menggunakan istilah bahasa Inggris, mereka lebih dapat memahami istilah yang dimaksud. Hal ini mungkin dipengaruhi oleh kenyataan bahwa pada saat mereka belajar komputer dan internet selama pendidikan formal, istilah-istilah yang digunakan adalah istilah berbahasa Inggris. Respondenresponden tersebut mengaku lebih sulit memahami padanan istilah komputer dan internet dalam bahasa Indonesia.

\section{3) Padanan Istilah dalam Bahasa} Indonesia Kurang Sesuai

Sebanyak 24 responden mengungkapkan alasan ini berkenaan dengan preferensi bahasa mereka. Mereka menyebutkan bahwa kebanyakan padanan istilah yang dipadankan dengan diterjemahkan ke dalam bahasa Indonesia tidak sesuai dengan maksud dari istilah bahasa Inggrisnya. Tidak sedikit yang padanan istilahnya mereka anggap aneh dan ambigu, misalnya bug menjadi 'kutu'. Ketika mereka berada dalam pembicaraan berkonteks komputer atau internet dan menyebutkan "ada 'kutu'..." ada kemungkinan pendengar akan salah mengartikan kutu yang dimaksud. Lain halnya jika penutur menyebut "ada bug...". Karena mereka memiliki pengetahuan yang sama dalam konteks tersebut, kesalahpahaman dapat dihindari. Ada juga yang menyebutkan kata-kata yang dipakai sulit dipahami karena bahasa Indonesia yang digunakan bukan merupakan bahasa umum yang dipakai sehari-hari, misalnya browse menjadi 'ramban'. Hal-hal ini menyebabkan mereka kesulitan ketika menggunakan padanan istilah komputer dan internet dalam bahasa Indonesia.

4) Istilah dalam Bahasa Inggris Lebih Singkat

Sebanyak empat responden menyebutkan bahwa alasan mereka memilih menggunakan istilah-istilah Jurnal Lingua Applicata Volume 2 Nomor 1 September 2018 
dalam bahasa Inggris karena istilah-istilah komputer dan internet pada bahasa tersebut dianggap lebih singkat daripada padanan istilahnya dalam bahasa Indonesia, misalnya mouse yang hanya terdiri dari satu suku kata dipadankan menjadi 'tetikus' dengan tiga suku kata, spacebar yang memiliki dua suku kata dipadankan menjadi 'batang spasi' dengan empat suku kata, keypad yang pada bentuk aslinya hanya memiliki dua suku kata dipadankan menjadi 'bantalan kunci' dengan lima suku kata dalam bahasa Indonesia. Hal ini dianggap kurang efektif daripada istilah-istilah aslinya dalam bahasa Inggris yang kemudian menyebabkan para responden tadi lebih memilih bahasa Inggris daripada bahasa Indonesia.

5) Tidak Tersedianya Padanan Istilah Bahasa Indonesia dalam Program yang Dijalankan.

Alasan terakhir yang dikemukakan oleh responden dalam memilih bahasa Inggris pada penggunaan istilah komputer dan internet adalah tidak tersedianya padanan istilah pada komputer atau alat yang mereka gunakan pada saat itu. Sebanyak tiga responden mengungkapkan alasan ini. Seorang responden bahkan mengungkapkan bahwa masih terdapat beberapa komputer atau program yang tidak menyediakan pilihan bahasa Indonesia. Hal ini memaksa mereka untuk menggunakan bahasa Inggris dalam penggunaan istilah komputer dan internet.

\section{Kesimpulan}

Dari 629 istilah komputer dan internet dalam bahasa Inggris, terdapat 711 padanan istilah bahasa Indonesianya yang tertera pada "Senarai Padanan Istilah". Jika dilihat dari 160 responden yang telah mengisi kuesioner, dapat disimpulkan bahwa pemahaman masyarakat Indonesia mengenai padanan istilah komputer dan internet sebenarnya sudah cukup tinggi. Hal ini tidak kemudian menjadikan bahasa Indonesia dipilih ketika menggunakan istilah-istilah bidang komputer dan/atau internet. Dapat dibuktikan bahwa dari 160 responden, sebanyak 147 atau 91,9\% responden memilih untuk menggunakan istilah komputer dan internet berbahasa Inggris. Terdapat sekurang-kurangnya lima alasan yang dikemukakan oleh para responden yang lebih memilih bahasa Inggris. Alasan-alasan tersebut antara lain: 1) istilah dalam bahasa Inggris lebih familier; 2) istilah dalam bahasa Inggris lebih 
mudah dipahami; 3) padanan istilah dalam bahasa Indonesia kurang sesuai; 4) istilah bahasa Inggris lebih singkat; 5) dan tidak tersedianya padanan istilah bahasa Indonesia pada komputer atau program yang mereka jalankan.

\section{Daftar Pustaka}

Badudu, J.S. (1983). Inilah Bahasa Indonesia yang Benar I. Jakarta: PT Gramedia pustaka Utama.

, J.S. (1985). Cakrawala Bahasa Indoensia. Jakarta: PT Gramedia pustaka Utama.

, J.S. (1986). Inilah Bahasa Indonesia yang Benar II. Jakarta: PT Gramedia pustaka Utama.

, J.S. (1989). Inilah Bahasa Indonesia yang Benar III. Jakarta: PT Gramedia pustaka Utama.

, J.S. (2007). Kamus Kata-Kata Serapan Asing dalam bahasa Indonesia. Jakarta: Kompas.

Bloom, B.S., Engelhart, M.D., Furst, E.J., Hill, W.H., Krathwohl, D.R. (1956). Taxonomy of Educational Objectives: The Classification of Educational Goals. Handbook I: Cognitive Domain. New York: David McKay Company.

Bloomfield, Leonard. (1995). Bahasa. Penerjemah: I. Sutikno. Jakarta: PT Gramedia Pustaka Utama.

Chaer, Abdul. (1994). Linguistic Umum. Jakarta: PT Rineka Cipta. . (2008). Morfologi Bahasa Indonesia (Pendekatan dan Proses). Jakarta: Rhineka Cipta.

Eddy, Nyoman Tusthi.(1989). Unsur Serapan Bahasa Asing dalam Bahasa Indonesia. Ende: Nusa Indah.

Fromkin, Victoria, Rodman, Robert, dan Hyams, Nina. ( 2011). An Introduction to Language. Toronto: Nelson Education, Ltd.

Haugen, Einar. ( 1972). The Ecology of Language: Essays by Einar Haugen. Stanford: Stanford University Press.
Hickey, Raymond (ed.). (2013). The Handbook of Language Contact. Chichester: Blackwell Publishing Ltd.

Kesuma, Tri Mastoyo Jati. (2007). Pengantar (Metode) Penelitian Bahasa. Yogyakarta. Carasvatibooks.

Kridalaksana, Harimurti. (2008). Kamus Linguistik. Jakarta: PT Gramedia Pustaka Utama.

Lowenberg, Peter. (1983). Lexical Modernization in Bahasa Indonesia: Functional Allocation and Variation Borrowing. Studies in The Linguistic Sciences 13 (2), 73-86.

Martinus, Surawan. (2008). Kamus Kata Serapan. Jakarta: PT Gramedia Pustaka Utama.

Ramlan, M. (1987). Sintaksis. Yogyakarta: CV Karyono.

Rahayu, Minto dan Akhmad Aminudin. (2013). Kajian Kebahasaaan Terhadap Peristilahan Internet. Epigram Vol. 10 No. 1, 7-11.

Soedjarwo. (1990). “Aspek Morfologi KataKata Serapan dalam Bahasa Indonesia." Laporan Penelitian. Lembaga Penelitian Universitas Diponegoro Semarang.

Sudijono, Anas. (2008). Pengantar Evaluasi Pendidikan. Jakarta: Raja Grafindo.

Sudaryanto, (1993). Metode dan Aneka Teknik Analisis Bahasa: Pengantar Penelitian Wahana Kebudayaan secara Linguistis. Yogyakarta: Duta Wacana University Press.

Syafar, Dian Noviani. (2012). "Kata Serapan Bahasa Inggris dalam Bahasa Indonesia: Kajian Morfologi dan Semantik." Tesis. Universitas Gadjah Mada.

Thomason, Sarah G.( 2001). Language Contact. Edinburg: Edinburg University Press Ltd.

Widagsa, Rudha. (2011). "Pemakaian Peristilahan Bahasa Inggris dalam Bidang Internet." Tesis. Universitas Gadjah Mada.

\section{Pustaka Laman}

Ermanesty, Esty. T.t. "Sejarah Komputer dan Internet". Tersedia di http://www.academia.edu/10402737/ 
Sejarah_Komputer_dan_Internet diakses pada 18 Mei 2016 pukul 16:41.

Kemkominfo. (2018). "Pengguna internet di Indonesia Capai 82 Juta". Tersedia di https://kominfo.go.id/content/detail/ 3980/kemkominfo-penggunainternet-di-indonesia-capai-82juta/o/berita_satker diakses pada 29 April 2018 pukul 21:15. 